\title{
KARAKTERISTIK FISIK, KIMIA DAN MIKROBIOLOGI SABUN SUSU KAMBING
}

\section{Physical, Chemical and Microbiological Characteristic of Goat Milk Soap}

\author{
Putri Dian Wulansari*, Dwi Wijayanti \\ Prodi Peternakan, Fakultas Pertanian, Universitas Perjuangan Tasikmalaya \\ Jl. Peta No 177 Tasikmalaya 46115 \\ *Penulis Korespondensi, Email: putridian@unper.ac.id
}

\begin{abstract}
ABSTRAK
Penelitian bertujuan untuk menganalisis potensi sabun susu kambing ditinjau dari karakteristik fisik, kimia dan mikrobiologi. Parameter yang diukur pada karakteristik fisik adalah nilai kekerasan, daya busa, warna, bau dan tekstur sabun. Karakteristik kimia sabun yang dianalisis terdiri dari kadar air, $\mathrm{pH}$, minyak mineral, alkali bebas, total asam lemak bebas, asam lemak bebas, dan lemak netral. Bakteri kulit Staphylococcus aureus, Escherichia coli dan Pseudomonas aeruginosa dipilih untuk menguji daya hambat yang dimiliki oleh sabun batang sebagai parameter dalam pengujian karakteristik mikrobiologi. Kualitas sabun susu kambing lebih rendah karena menghasilan total asam lemak dan lemak mineral dibandingkan dengan sabun kontrol yang dihasilkan. Sabun susu kambing yang dihasilkan hanya memiliki daya hambat terhadap bakteri Staphylococcus aureus. sabun susu kambing pada penelitian ini memenuhi syarat SNI 06-3532-1994, kecuali kandungan minyak mineral.
\end{abstract}

Kata kunci: Kefir, Konsentrat kefir, Sabun, Susu kambing,

\section{ABSTRACT}

The research aims to analyze the potential of goat milk soap in terms of physical, chemical and microbiological characteristics. The parameters measured on physical characteristics are hardness value, foam strength, color, odors and soap texture. The chemical characteristics of the soap analyzed consist of water content, $\mathrm{pH}$, mineral oil, free alkali, total free fatty acids, free fatty acids, and neutral fat. Skin bacteria Staphylococcus aureus, Escherichia coli and Pseudomonas aeruginosa were selected to test the inhibitory properties of bar soap as a parameter in testing microbiological characteristics. The quality of goat milk soap is lower because it produces total fatty acids and mineral fats compared to the control soap produced. The resulting goat milk soap has only inhibitory power against Staphylococcus aureus bacteria. The conclusion is goat milk soap produced meets SNI 063532-1994 requirements, except for its mineral oil content.

Keywords: Concentrate Kefir, Goat Milk, Kefir, Soap

\section{PENDAHULUAN}

Sabun mandi merupakan salah satu kebutuhan pokok untuk menjaga kebersihan badan. Perencevich et al., (2001) menyatakan bahwa $45 \%$ dari sabun yang disurvei mengandung agen antibakteri kimia (triclosan dan triclocarban) yang memiliki efek buruk yaitu munculnya resistensi bakteri patogen. Hal tersebut mengakibatkan sabun alami saat ini banyak diminati oleh konsumen karena manfaat fungsional yang ditawarkannya. Penggunaan bahan alami saat ini sudah banyak diteliti untuk melihat manfaatnya saat ditambahkan dalam proses pembuatan sabun.

Mutu sabun batang dipengaruhi oleh komponen utama dalam pembuatan sabun. Komponen utama dalam pembuatan sabun adalah bahan yang mengandung asam lemak 
(Sari et al., 2010). Sabun merupakan hasil asam lemak yang terhidrolisis dengan basa yang dikenal dengan peristiwa saponifikasi (Sari et al., 2010). Susu kambing memiliki kandungan asam lemak jenuh yang tinggi (69.9\%) dengan komposisi asam lemak paling dominan adalah asam palmiat (26.41\%) dan asam oleat (25.45\%) (Sumarmono dan Sulistyowati, 2015). Asam palmiat dan asam oleat merupakan asam lemak dominan yang ditemukan di sabun cuci, sabun toilet, sabun medis dan sabun antiseptik (Oghome et al., 2012).

Susu kambing merupakan bahan yang bisa digunakan dalam pembuatan sabun karena memiliki sifat antibakteri alami. Sifat antibakteri alami dalam susu bersifat aman apabila digunakan terus-menerus. Wulansari et al., (2018) menyatakan bahwa konsentrat susu kambing fermentasi memiliki daya hambat setara 60\% dari kloramfenikol (antibakteri kimia) terhadap bakteri Staphylococcus aureus. Oleh karena itu, penambahan susu kambing berpotensi meningkatkan nilai fungsional pada sabun yang dihasilkan. Tujuan penelitian untuk mengetahui potensi sabun susu kambing ditinjau dari karakteristik fisik, kimia dan mikrobiologinya.

\section{BAHAN DAN METODE}

\section{Bahan}

Bahan penelitian adalah susu kambing peranakan etawah segar dari Kelompok Peternakan Agribisnis As-Salam Kota Tasikmalaya, Jawa Barat, Indonesia. Minyak kelapa sawit (Merek Sania), minyak kelapa (Merek Braco), minyak zaitun (Merek Pietro Coricelli) dan $\mathrm{NaOH}$ (Merek Brataco) digunakan dalam proses pembuatan sabun. Sabun susu kambing dalam penelitian ini merupakan sabun yang ditambahkan susu kambing pasteurisasi, kefir susu kambing, konsentrat kefir susu kambing dan whey kefir susu kambing. Susu kambing di pasteurisasi menggunakan metode HTST (High Temperature Short Time) sedangkan proses pembuatan kefir, konsentrat kefir dan whey kefir susu kambing menggunakan prosedur penelitian Wulansari et al. (2018), yaitu kefir dibuat dari susu kambing yang dipasteurisasi menggunakan metode HTST dan ditambahkan grain kefir sebanyak $10 \%$. Proses pembuatan kefir menggunakan suhu ruang dengan fermentasi selama 24 jam. Konsentrat kefir susu kambing merupakan kefir yang dikurangi kadar air dengan metode berge (penggantungan) pada suhu ruang selama 2 jam menggunakan cloth bag (kain saring), sedangkan air hasil saringan merupakan whey.

\section{Alat}

Alat untuk mendukung penelitian ini adalah panci, termometer, inkubator, hand blender, timbangan digital, gelas ukur, toples, cetakan sabun, dan alat pemotong sabun. Alat laboratorium untuk pengujian parameter diantaranya $\mathrm{pH}$ meter, titrasi, oven, cawan petri, texture analyzer, pipet, beker, gelas ukur, dan corong.

\section{Desain Penelitian}

Penelitian ini terdiri dari 5 perlakuan (masing-masing diulang 5 kali) yaitu $\mathrm{K}$ (Kontrol menggunakan aquades), SKP (Susu Kambing Pasteurisasi), KSK (Kefir Susu Kambing), KKSK (Konsentrat Kefir Susu Kambing), dan WKSK (Whey Kefir Susu Kambing). masingmasing perlakuan ditambahkan pada sediaan sabun sebagai berikut: sediaan sabun $+24 \%$ akuades, sediaan sabun $+24 \%$ susu kambing pasteurisasi, sediaan sabun $+24 \%$ kefir susu kambing, sediaan sabun $+24 \%$ konsentrat kefir susu kambing, dan sediaan sabun $+24 \%$ whey kefir susu kambing.

\section{Tahapan Penelitian}

Persiapan pertama yaitu menentukan perlakuan penelitian: SKP (Susu Kambing Pasteurisasi), KSK (Kefir Susu Kambing), KKSK (Konsentrat Kefir Susu Kambing), dan WKSK (Whey Kefir Susu Kambing). Pembuatan sabun batang dengan metode cold process. Sediaan sabun (formula) yang digunakan terdiri dari 31\% minyak kelapa sawit $+24 \%$ minyak kelapa $+11 \%$ minyak zaitun $+10 \% \mathrm{NaOH}$. Prosedur penelitian Sukawaty et al., 
(2016) dengan modifikasi yaitu dilakukan dengan cara $\mathrm{NaOH}$ dilarutkan dalam masingmasing perlakuan. Larutan $\mathrm{NaOH}$ kemudian dicampurkan dengan minyak sesuai formula. Campuran larutan tersebut diaduk menggunakan hand blender sampai homogen dan proses trace. Campuran dicetak dan didiamkan selama 24 jam (sampai mengeras) kemudian dikeluarkan dari cetakan. Sabun yang dihasilkan disimpan di rak terbuka pada suhu ruang dan disimpan selama 30 hari untuk kemudian dilakukan analisis.

Uji nilai kekerasan menggunakan texture analyzer (Retnowati et al., 2013). Pengukuran daya busa (Mumpuni dan Sasongko, 2017) dengan cara pengukuran tinggi busa larutan sampel setelah pengocokan. Penentuan karakteristik untuk tekstur permukaan (Harris et al., 2016), bau (Ayu et al., 2010), dan warna sabun (Onyegbado et al., (2002) dilakukan dengan metode deskriptif.

Uji kadar air, alkali bebas, total asam lemak, minyak mineral, asam lemak bebas dan lemak netral diuji dengan menggunakan prosedur SNI 06-3532-1994 (SNI, 1994). Pengujian $\mathrm{pH}$ dengan pengukuran menggunakan $\mathrm{pH}$ meter metode Mumpuni dan Sasongko (2017). Prosedur pengujian daya hambat dimodifikasi berdasarkan prosedur penelitian Singh et al. (1979). Pengujian daya hambat menggunakan metode difusi cakram pada bakteri kulit Staphylococcus aureus, Escherichia coli, dan Pseudomonas aeruginosa.

\section{Metode}

Metode penelitian yang digunakan adalah metode eksperimental menggunakan Rancangan Acak Lengkap (RAL).

\section{Prosedur Analisis}

Data dianalisis menggunakan ANOVA dengan uji Duncan's Multiple Range Test dengan angka toleransi kesalahan yang diterapkan 5\% (Steel and Torrie, 1996).

\section{HASIL DAN PEMBAHASAN}

\section{Karakteristik Fisik}

Penambahan susu kambing tidak memengaruhi nilai kekerasan sabun yang dihasilkan $(P>0.05)$. Sabun paling keras adalah sabun susu kambing pasteurisasi, sedangkan sabun kontrol merupakan sabun yang paling lunak (Tabel 1). Tingkat kekerasan sabun di tentukan dengan kedalaman needle atau jarum pada alat texture analyzer yang masuk ke dalam sabun. Semakin dalam jarum masuk ke dalam sabun, semakin tinggi pula nilai kekerasannya, yang menunjukkan bahwa sabun tersebut semakin lunak. Perbedaan total padatan yang dimiliki susu kambing sebanyak 18.1\% (Raynal-Ljutovac et al.,2008), kefir susu kambing sebanyak $14.6 \%$ (Setyawardani et al., 2014) dan konsentrat kefir susu kambing sebanyak $47.5 \%$ (Wulansari et al., 2018) pada proses pembuatan sabun tidak memengaruhi nilai kekerasan sabun yang dihasilkan. Widiyanti (2009), menyatakan bahwa sabun dengan kekerasan lebih tinggi memiliki masa simpan yang lebih panjang dari pada sabun yang tingkat kekerasannya rendah.

Data Tabel 1 menunjukkan bahwa penambahan susu kambing tidak memengaruhi daya busa sabun yang dihasilkan $(P>0.05)$. Sabun konsentrat kefir susu kambing memiliki daya busa paling tinggi (47.7\%), tidak jauh berbeda dengan daya busa yang dihasilkan oleh sabun kontrol (47\%) (Tabel 1). Hernani et al., (2010) menyatakan bahwa salah satu parameter penting lain yaitu pengukuran busa untuk menentukan mutu sabun. Peran busa saat digunakan adalah sebagai pembersih dan limpahan wangi sabun. Sugesti konsumen menurut Mumpuni dan Sasongko (2017), adalah sabun yang menghasilkan banyak busa merupakan sabun yang baik, padahal tidak selalu sabun yang menghasilkan busa yang banyak itu memiliki kemampuan membersihkan yang baik. Martin et al., (1993), menyatakan bahwa produksi busa ini salah satunya dipengaruhi dengan adanya tambahan bahan aktif sabun. 
Tabel 1. Uji nilai kekerasan, daya busa, warna, bau dan tekstur sabun susu kambing

\begin{tabular}{|c|c|c|c|c|c|}
\hline Perlakuan & $\begin{array}{l}\text { Nilai } \\
\text { kekerasan } \\
\text { (N) }\end{array}$ & $\begin{array}{c}\text { Daya busa } \\
(\%)\end{array}$ & $\begin{array}{l}\text { Warna } \\
\text { sabun* }\end{array}$ & $\mathrm{Bau}^{\star}$ & $\begin{array}{c}\text { Tekstur } \\
\text { permukaa } \\
n^{\star}\end{array}$ \\
\hline $\mathrm{K}$ & $37.83 \pm 2.77$ & $47 \pm 7$ & Putih & $\begin{array}{c}\text { Bau } \mathrm{NaOH} \text { sangat } \\
\text { tajam }\end{array}$ & Kasar \\
\hline SKP & $27.85 \pm 10.49$ & $38.6 \pm 7.51$ & Kuning & Tercium bau susu & Halus \\
\hline KSK & $36.82 \pm 13.52$ & $37.6 \pm 4.51$ & Kuning & Tercium bau susu & Halus \\
\hline KKSK & $31.66 \pm 5.38$ & $47.6 \pm 6.67$ & Kuning & Tercium bau susu & Halus \\
\hline WKSK & $35.19 \pm 12.12$ & $36 \pm 12.17$ & $\begin{array}{l}\text { Sedikit } \\
\text { Kuning }\end{array}$ & $\begin{array}{l}\text { Tidak tercium bau } \\
\mathrm{NaOH} \text { dan susu }\end{array}$ & Halus \\
\hline
\end{tabular}

Perlakuan $=\mathrm{K}$ (kontrol menggunakan aquades); SKP (Susu Kambing Pasteurisasi); KSK (Kefir Susu kambing); KKSK (Konsentrat Kefir Susu Kambing); WKSK (Whey Kefir Susu Kambing). *berdasarkan analisis deskriptif

Tabel 1 menunjukkan sabun susu kambing yang dihasilkan cenderung berwarna kuning dibandingkan dengan sabun kontrol. Onyegbado et al. (2002), menyatakan bahwa sabun batang yang baik memiliki warna putih susu. Penambahan susu kambing dalam sabun mampu memengaruhi warna sabun hal ini sesuai penelitian sebelumnya yang dilakukan oleh Ayu et al. (2010), menyatakan bahwa bahan baku yang digunakan akan memengaruhi warna sabun. Susu kambing mengandung karoten yang merupakan pigmen warna alami (Le Jaouen, 1981). Karoten menurut Ginting and Pasaribu (2005) merupakan pigmen yang berwarna kuning dan berada dalam lemak susu. Hal ini yang menyebabkan sabun susu kambing berwarna lebih kuning dari sabun kontrol. Kandungan asam lemak susu kambing juga memberikan pengaruh warna sabun yang dihasilkan. Hambali et al., (2005) menyatakan bahwa pemilihan bahan baku khususnya bahan baku yang mengandung asam lemak dalam formula sabun dapat memengaruhi secara signifikan terhadap warna sabun yang dihasilkan.

Penambahan susu kambing pada pembuatan sabun mengakibatkan sabun yang dihasilkan cenderung beraroma susu, kecuali pada sabun whey kefir susu kambing yang tidak memiliki aroma susu maupun $\mathrm{NaOH}$. Penentuan karakteristik bau berdasarkan Ayu et al. (2010), yaitu dilakukan dengan cara membandingkan sabun yang dihasilkan dengan perlakuan yang ditambahkan dalam penelitian ini yaitu susu. Karakteristik bau yang ada pada sabun belum ditentukan secara detail dalam SNI (1994). Bau susu dalam sabun yang dihasilkan tidak mengganggu penciuman sedangkan penambahan akuades sebagai kontrol menghasilkan sabun dengan bau $\mathrm{NaOH}$ yang cukup tajam sehingga mengganggu penciuman.

Tabel 1 menunjukkan bahwa permukaan tekstur sabun susu kambing cenderung lebih halus dibandingkan sabun kontrol. Harris et al. (2016) menyatakan bahwa tekstur permukaan sabun yang baik adalah permukaan sabun bertekstur halus. Asam stearat dan asam laurat berpengaruh terhadap tekstur sabun yang dihasilkan (Hambali et al., 2005). Sumarmono and Sulistyowati (2015) menyatakan bahwa susu kambing mengandung asam stearat sebanyak $12.14 \%$ dan asam laurat sebanyak $1.89 \%$. Susu kambing memiliki partikel lemak yang lebih kecil sehingga lebih merata dan homogen (Attaie \& Richter, 2000), sehingga mampu menghasilkan sabun susu kambing dengan permukaan yang lebih halus dari pada sabun kontrol.

\section{Karakteristik Kimia}

Berdasarkan Tabel 2, perbedaan penambahan susu kambing terhadap kadar air sabun ternyata tidak berpengaruh nyata $(P>0.05)$. SNI 06-3532-1994 menyatakan syarat mutu produk sabun diantaranya kadar air pada sabun batang maksimal $15 \%$. Rataan kadar air sabun pada penelitian ini sebesar $7.55 \%$, dengan demikian semua perlakuan menghasilkan sabun dengan kadar air yang memenuhi standar SNI. Rataan kadar air pada 
penelitian ini lebih rendah yaitu: 13.28 - 14.92\% pada sabun minyak jarak (Sari, Kasih, et al., 2010), 17.76 - 32.48 pada sabun VCO (Sari et al., 2010) dan 17\% pada sabun ekstrak lengkuas (Hernani et al., 2010). Sabun akan lebih mudah menyusut apabila kadar airnya lebih tinggi dari standar SNI (Spitz, 1996). Sukawaty et al. (2016) menyatakan bahwa peningkatan lama proses penyimpanan dapat menurunkan kadar air pada sabun karena adanya proses penguapan.

Tabel 2. Uji kadar air, pH dan minyak mineral sabun susu kambing

\begin{tabular}{cccc}
\hline Perlakuan & Kadar air (\%) & Ph & Minyak mineral \\
\hline K & $8.20 \pm 3.76$ & $10.10 \pm 0.20$ & Negatif \\
SKP & $8.36 \pm 0.89$ & $10.13 \pm 0.12$ & Positif \\
KSK & $6.53 \pm 0.38$ & $10.17 \pm 0.16$ & Positif \\
KKSK & $9.11 \pm 1.54$ & $10.76 \pm 1.15$ & Positif \\
WKSK & $5.55 \pm 1.54$ & $10.00 \pm 0.00$ & Positif \\
\hline
\end{tabular}

Keterangan $=\mathrm{K}$ (kontrol menggunakan aquades); SK (Susu Kambing Pasteurisasi); KSK (Kefir Susu kambing); KKSK (Konsentrat Kefir Susu Kambing); WKSK (Whey Kefir Susu Kambing).

Tabel 2 menunjukan bahwa penambahan susu kambing terhadap $\mathrm{pH}$ sabun tidak berpengaruh nyata $(P>0.05)$. Rataan $\mathrm{pH}$ sabun yang dihasilkan sebesar 10.23 lebih tinggi dari penelitian sebelumnya dengan nilai pH 9.7-9.9 (Mumpuni \& Sasongko, 2017). Hambali et al. (2005) menyatakan bahwa ph 9-11 merupakan kisaran nilai pH untuk sabun mandi. Produk kosmetik sangat penting untuk mengukur nilai $\mathrm{pH}$, hal ini dikarenakan $\mathrm{pH}$ mampu memengaruhi daya serap pada kulit. Nilai yang tsangat tinggi atau rendah pada $\mathrm{pH}$ akan menghasilkan iritasi kulit yang disebabkan oleh daya serap kulit (Wasitaatmadja, 1997).

Ayu et al. (2010) menyatakan bahwa nilai pH dapat dipengaruhi oleh jenis dari bahan baku yang digunakan. Penambahan bahan yang bersifat asam dapat mengontrol nilai $\mathrm{pH}$ pada sabun (Hernani et al., 2010; Rahaadia, 2006). Konsentrat kefir susu kambing memiliki $\mathrm{pH}$ yang asam yaitu 3.24 (Wulansari et al., 2018) akan tetapi penambahan konsentrat kefir susu kambing sebanyak $24 \%$ dari total formulasi belum mampu menurunkan $\mathrm{pH}$ sabun yang dihasilkan.

Penambahan susu kambing berpengaruh nyata $(P<0.05)$ terhadap minyak mineral sabun ditunjukkan pada Tabel 2. Sabun kontrol memenuhi syarat karena tidak ditemukan minyak mineral didalamnya, sedangkan semua sabun yang mengandung susu kambing positif mengandung minyak mineral pada penelitian ini sehingga dinyatakan tidak memenuhi syarat mutu. SNI 06-3532-1994 menyatakan bahwa sabun yang baik adalah sabun yang tidak ditemukan minyak mineral di dalamnya. Cara pengujian minyak mineral sabun adalah dengan titrasi menggunakan air, apabila tidak menghasilkan kekeruhan pada saat titrasi maka itu merupakan tanda bahwa minyak mineralnya tidak lebih dari 0.05\% (SNI, 1994). Naomi et al., (2013) menyatakan bahwa apabila sabun memiliki minyak mineral maka akan memengaruhi emulsi sabun dengan air.

Minyak mineral menurut Chasani et al., (2015), merupakan minyak yang tidak dapat disabunkan karena tidak terdapat gugus ester dan basa yang ditambahkan secara berlebihan tidak membuat proses saponifikasi berlangsung sehingga wujudnya tetap sebagai minyak. Ketepatan konsentrasi $\mathrm{NaOH}$ dalam pembuatan sabun sangat penting sehingga menghasilkan sabun yang memenuhi syarat mutu untuk kandungan minyak mineral (Langingi et al., 2012).

Perbedaan penambahan susu kambing tidak berpengaruh nyata $(P>0.05)$ terhadap alkali bebas sabun (Tabel 3). SNI 06-3532-1994 menyatakan bahwa batas maksimal kandungan alkali bebas pada sabun untuk memenuhi syarat mutu adalah sebesar $0.01 \%$ (SNI, 1994). Rataan alkali bebas sabun pada penelitian ini sebesar $0.0167 \%$, dengan demikian semua perlakuan menghasilkan sabun dengan kadar alkali bebas yang memenuhi standar SNI. Alkali bebas pada penelitian ini lebih rendah dari penelitian lain seperti : 0.120.57 pada sabun minyak jarak (Sari et al., 2010) dan 0.03-0.047 pada sabun VCO (Sari et al., 2010). Langingi et al. (2012) menyatakan bahwa alkali bebas adalah adanya garam 
asam lemak pada sabun yang dihasilkan dari alkali yang tidak terikat dengan asam lemak. Alkali bebas yang jumlahnya melebihi standar dapat mengakibatkan kulit kering dan iritasi karena sifatnya yang keras (Hernani et al., 2010; Sari et al., 2010).

Tabel 3. Alkali bebas, total asam lemak, asam lemak bebas dan lemak netral sabun susu kambing

\begin{tabular}{ccccc}
\hline Perlakuan & $\begin{array}{c}\text { Alkali bebas } \\
(\%)\end{array}$ & $\begin{array}{c}\text { Total asam } \\
\text { lemak (\%) }\end{array}$ & $\begin{array}{c}\text { Asam lemak } \\
\text { bebas }(\%)\end{array}$ & $\begin{array}{c}\text { Lemak netral } \\
(\%)\end{array}$ \\
\hline K & $0.01 \pm 0.01$ & $76.1 \pm 18.99^{\mathrm{ab}}$ & $0.79 \pm 0.78$ & $1.67 \pm 2.33$ \\
SKP & 0 & $54.17 \pm 6.65^{\mathrm{b}}$ & $0.81 \pm 0.12$ & $0.18 \pm 0.06$ \\
KSK & 0 & $67.67 \pm$ & $1.05 \pm 0.24$ & $0.55 \pm 0.47$ \\
& & $10.49^{\mathrm{ab}}$ & & \\
KKSK & $0.08 \pm 0.13$ & $79.87 \pm$ & $1.85 \pm 0.81$ & $0.15 \pm 0.06$ \\
WKSK & 0 & $82.3 \pm 1.07^{\mathrm{ab}}$ & $1.15 \pm 0.11$ & $2.46 \pm 2.83$
\end{tabular}

Keterangan $=\mathrm{K}$ (kontrol menggunakan aquades); SK (Susu Kambing Pasteurisasi); KSK (Kefir Susu kambing); KKSK (Konsentrat Kefir Susu Kambing); WKSK (Whey Kefir Susu Kambing). Superskrip sama pada kolom menunjukan tidak ada berbeda nyata $(P<0.05)$

Perbedaan penambahan susu kambing terhadap total asam lemak sabun berpengaruh nyata $(\mathrm{P}<0.05)$. Sabun whey kefir susu kambing menghasilkan total asam lemak paling tinggi (82.3\%). Total asam lemak paling rendah dimiliki oleh sabun susu kambing pasteurisasi (54.17\%) (Tabel 3). SNI 06-3532-1994 menetapkan bahwa sabun yang memenuhi syarat mutu adalah sabun dengan total asam lemak minimal $64 \%$ (SNI, 1994). Sabun susu kambing pasteurisasi berada di bawah ambang batas total asam lemak yang harus dimiliki. Hasil penelitian ini lebih tinggi dibandingkan penelitian Langingi et al. (2012) yang memiliki rataan total asam lemak sabun sebanyak $75.08 \%$.

Tabel 3 menunjukkan bahwa perbedaan penambahan susu kambing tidak berpengaruh nyata $(P>0.05)$ terhadap asam lemak bebas. SNI 06-3532-1994 menetapkan asam lemak bebas sabun yang memenuhi syarat mutu adalah asam lemak bebas dengan nilai kurang dari $2.5 \%$ (SNI, 1994) dan hasil asam lemak bebas pada penelitian ini memenuhi syarat. Rataan asam lemak pada penelitian ini sebanyak $0.93 \%$ jauh lebih rendah dari penelitian Langingi et al. (2012) dengan kandungan asam lemak bebas sebesar $1.5235 \%$.

Asam lemak yang tinggi pada sabun dapat menimbulkan ketengikan. Ketengikan ini diakibatkan oleh reaksi hidrolisis terhadap minyak yang terjadi karena adanya asam lemak dalam keadaan bebas dan tidak berikatan dengan gliserol. Rasa dan bau yang tengik tidak disukai akibat dari degradasi asam lemak bebas tersebut, sehingga keberadaan asam lemak bebas tidak dikehendaki dalam sabun (Zulkifli \& Estiasih, 2014). Ayu et al. (2010) menyatakan bahwa daya bersih dari sabun dapat berkurang dalam proses pembersihan karena adanya komponen asam lemak bebas. Asam lemak minyak dan jumlah basa yang digunakan dalam formula pembuatan sabun akan memengaruhi kadar asam lemak bebas yang dihasilkan oleh sabun. Kadar asam lemak bebas sabun dipengaruhi oleh kadar asam lemak minyak yang digunakan dan jumlah basa yang digunakan. Penambahan $\mathrm{NaOH}$ harus tepat sehingga dapat bereaksi seluruhnya dengan asam lemak yang digunakan. Penambahan $\mathrm{NaOH}$ yang terlalu banyak dari kebutuhannya akan menimbulkan iritasi kulit, sedangkan kekurangan $\mathrm{NaOH}$ akan menghasilkan sabun dengan banyak kandungan asam lemak bebas sehingga emulsi sabun dengan kotoran dapat terganggu (Hardian \& Ali, 2014).

Tabel 3 menunjukkan bahwa perbedaan penambahan susu kambing tidak memengaruhi lemak netral dari sabun yang dihasilkan $(P>0.05)$. SNI 06-3532-1994 menyatakan bahwa lemak netral pada sabun batang harus kurang dari 2,5\% untuk memenuhi syarat mutu sabun batang (SNI, 1994). Nilai lemak netral sabun yang dihasilkan pada penelitian ini ada pada kategori mutu SNI. Sabun susu pasteurisasi, sabun kefir susu 
kambing dan sabun konsentrat kefir susu kambing memiliki lemak netral yang jauh lebih kecil dari sabun kontrol. Sabun whey kefir susu kambing memiliki lemak netral yang berada di ambang batas dari jumlah lemak netral yang diperbolehkan yaitu sebanyak $2.46 \%$. Sabun dengan kandungan lemak netral yang tinggi dapat menurunkan daya sabun untuk membersihkan kotoran, hal ini karena lemak netral dalam sabun tersebut akan mengikat lemak dalam sabun bukan kotaran (Chasani et al., 2015).

\section{Karakteristik Mikrobiologi}

Data yang disajikan pada Tabel 4, perbedaan penambahan susu kambing tidak memengaruhi daya hambat untuk bakteri kulit Staphylococcus aureus, Escheria coli dan Pseudomonas aeruginosa ( $P>0.05$ ). Hasil penelitian ini menunjukkan bahwa penambahan susu kambing dalam pembuatan sabun tidak menjadikan sabun tersebut lebih efektif untuk menahan pertumbuhan bakteri Staphylococcus aureus dibandingkan dengan sabun kontrol. Sesuai dengan penelitian Oghome et al. (2012) menyatakan bahwa sabun yang ditambahkan zat antibakteri sintetik pun (triclosan sebanyak $0.1-0.45 \% \mathrm{w} / \mathrm{v}$ ) menghasilkan sabun yang tidak lebih efektif dalam mencegah penyakit dan bakteri dibandingkan dengan sabun biasa. Semua perlakuan dalam penelitian ini menghasilkan sabun yang tidak memiliki aktivitas untuk menahan pertumbuhan bakteri Escheria coli dan Pseudomonas aeruginosa.

Tabel 4. Daya hambat bakteri sabun susu kambing

\begin{tabular}{cccc}
\hline Perlakuan & $\begin{array}{c}\text { Staphylococcus } \\
\text { aureus }(\mathbf{c m})\end{array}$ & Escheria coli $(\mathbf{c m})$ & $\begin{array}{c}\text { Pseudomonas } \\
\text { aeruginosa }(\mathbf{c m})\end{array}$ \\
\hline K & $1.41 \pm 0.91$ & 0 & 0 \\
SKP & $1.21 \pm 0.09$ & 0 & 0 \\
KSK & $1.11 \pm 0.13$ & 0 & 0 \\
KKSK & $1.31 \pm 0.36$ & 0 & 0 \\
WKSK & $0.99 \pm 0.22$ & 0 & 0 \\
\hline
\end{tabular}

Keterangan $=\mathrm{K}$ (kontrol menggunakan aquades); SK (Susu Kambing Pasteurisasi); KSK (Kefir Susu kambing); KKSK (Konsentrat Kefir Susu Kambing); WKSK (Whey Kefir Susu Kambing).

Sabun kosentrat kefir susu kambing memiliki daya hambat paling tinggi yaitu dengan diameter sebesar $1.303 \mathrm{~cm}$. Klasifikasi respon hambatan pertumbuhan bakteri Staphylococcus aureus pada penelitian ini berada dikategori respon hambatan pertumbuhan lemah dengan diameter daya hambat $1-1.5 \mathrm{~cm}$ (Mulyadi et al.,2017). Sabun pada penelitian ini memiliki daya hambat pada bakteri Staphylococcus aureus lebih tinggi dari pada diameter daya hambat penelitian sebelumnya dengan penambahan antibakteri alami dari beberapa tanaman. Penambahan 7.5\% minyak kemangi dilakukan oleh Muthmainnah et al., (2014) menghasilkan diameter hambat $0.98 \mathrm{~cm}$, penambahan ekstrak kumis kucing oleh Yulianti, Nugraha, dan Nurdianti (2015) menghasilkan diameter hambat $0.74 \mathrm{~cm}$, sedangkan penambahan 5-15\% ekstrak etanol bunga pacar air oleh Dimpudus (2017) menghasilkan diameter hambat $0.66 \mathrm{~cm}$.

\section{SIMPULAN}

Penelitian ini menunjukan bahwa sabun susu kambing yang dihasilkan sesuai anjuran mutu dari SNI 06-3532-1994, kecuali kandungan minyak mineralnya. Sabun susu kambing memiliki daya hambat sama dengan sabun kontrol terhadap bakteri bakteri Staphylococcus aureus, akan tetapi tidak memiliki efektifitas untuk menahan pertumbuhan bakteri Escherichia coli dan Psedomonas aeruginosa. 


\section{UCAPAN TERIMA KASIH}

Ucapan terimakasih untuk Universitas Perjuangan Tasikmalaya dengan pemberian dana penelitian Skim Penelitian Berpotensi HAKI melalui LP2M (73/SK/Rek./UP/2018).

\section{DAFTAR PUSTAKA}

Attaie, R., \& Richter, R. (2000). Size distribution of fat globules in goat milk. Journal of dairy science, 83(5), 940-944.

Ayu, D. F., Ali, A., \& Sulaiman, R. (2010). Evaluasi mutu sabun padat dari minyak goreng bekas makanan jajanan di Kecamatan Tampan Kota Pekanbaru dengan penambahan natrium hidroksida dan lama waktu penyabunan. Paper presented at the Prosiding Konferensi dan Seminar Nasional XX Badan Kerjasama Pusat Studi LingkunganSeminar Nasional Lingkungan Hidup.

Badan Standarisasi Nasional. (1994). Standar Nasional Indonesia (SNI). SNI 06-3532-1994. Sabun Mandi. Dewan Standarisasi Indonesia. Jakarta

Chasani, M., Widyaningsih, S., \& Mubarok, A. (2015). Sintesis dan Karakterisasi Sabun Natrium dari Minyak Biji Nyamplung (Calophyllum inophyluum L.) serta Uji Aktivitas Antibakteri Terhadap Staphilococcus aureus. Molekul, 10(1), 66-73.

Dimpudus, S. A. (2017). Formulasi Sediaan Sabun Cari Antiseptik Ekstrak Etanol Bunga Pacar Air (Impatiens balsamina L.) dan Uji Efektivitasnya Terhadap Bakteri Staphylococcus aureus Secara In Vitro. Pharmacon, 6(3), 208-215

Ginting, N., \& Pasaribu, E. (2005). Pengaruh temperatur dalam pembuatan yogurt dari berbagai jenis susu dengan menggunakan Lactobacillus bulgaricus dan Streptococcus thermophilus. Jurnal Agribisnis Peternakan, 1(2), 73-77.

Hambali, E., Bunasor, T. K., Suryani, A., \& Kusumah, G. A. (2005). Aplikasi dietanolamida dari asam laurat minyak inti sawit pada pembuatan sabun transparan. Journal of Agroindustrial Technology, 15(2), 46-53.

Hardian, K., \& Ali, A. (2014). Evaluasi Mutu Sabun Padat Transparan dari Minyak Goreng Bekas dengan Penambahan Sls (Sodium Lauryl Sulfate) dan Sukrosa. Jurnal Online Mahasiswa Fakultas Pertanian Universitas Riau, 1(2), 1-11.

Harris, M. V., Darmanto, Y. S., \& Riyadi, P. H. (2016). Pengaruh Kolagen Tulang Ikan Air Tawar Yang Berbeda Terhadap Karakteristik Fisik Dan Kimia Sabun Mandi Padat. Jurnal Pengolahan dan Bioteknologi Hasil Perikanan, 5(1), 118-124.

Hernani, H., Bunasor, T. K., \& Fitriati, F. (2010). Formula Sabun Transparan Antijamur dengan Bahan Aktif Ekstrak Lengkuas (Alpinia galanga L. Swartz.). Buletin Penelitian Tanaman Rempah dan Obat, 21(2), 192-205.

Langingi, R., Momuat, L. I., \& Kumaunang, M. G. (2012). Pembuatan Sabun Mandi Padat dari VCO yang Mengandung Karotenoid Wortel. Jurnal Mipa Unsrat Online, 1(1), 2023.

Le Jaouen, J. C. (1981). Milking and the technology of milk and milk products. In C. Gall (Ed.), goat production (pp. 345). New York: Academic Press.

Martin, A., Swarbrick, J., \& Cammarata, A. (1993). Buku Farmasi Fisik Edisi Ke-tiga. Jilid 2. Terjemahan: UI Press, Jakarta.

Mulyadi, M., Wuryanti, W., \& Sarjono, P. R. (2017). Konsentrasi Hambat Minimum (KHM) Kadar Sampel Alang-Alang (Imperata cylindrica) dalam Etanol Melalui Metode Difusi Cakram. Jurnal Kimia Sains dan Aplikasi, 20(3), 130-135.

Mumpuni, A. S., \& Sasongko, H. (2017). Mutu sabun transparan ekstrak etanol herba pegagan (Centella asiatica L.) setelah penambahan sukrosa. Pharmaciana, 7(1), 7178.

Muthmainnah, R., Rubiyanto, D., \& Julianto, T. S. (2014). Formulasi Sabun Cair Berbahan Aktif Minyak Kemangi Sebagai Antibakteri Dan Pengujian Terhadap Staphylococcus Aureus. IJCR (Indonesian Journal of Chemical Research), 2(1), 44-50. 
Naomi, P., Gaol, A. M. L., \& Toha, M. Y. (2013). Pembuatan sabun lunak dari minyak goreng bekas ditinjau dari kinetika reaksi kimia. Jurnal Teknik Kimia, 19(2).

Oghome, P., Eke, M., \& Kamalu, C. (2012). Characterization of Fatty Acid Used in Soap Manufacturing in Nigeria: Laundry, Toilet, Medicated and Antiseptic Soap. Int $J$ Modern Engin Res, 2(4), 2930-2934.

Onyegbado, C., lyagba, E., \& Offor, O. (2002). Solid soap production using plantain peel ash as source of alkali. Journal of Applied Sciences and Environmental Management, 6(1), 73-77.

Perencevich, E. N., Wong, M. T., \& Harris, A. D. (2001). National and regional assessment of the antibacterial soap market: a step toward determining the impact of prevalent antibacterial soaps. American journal of infection control, 29(5), 281-283.

Rahaadia, P. K. (2006). Komposisi dan Evaluasi Hasil Pembuatan Sabun Padat Virgin Coconut Oil (VCO) dengan Sari Jeruk NIpis. (Skripsi), Universitas Andalas, Padang.

Raynal-Ljutovac, K., Lagriffoul, G., Paccard, P., Guillet, I., \& Chilliard, Y. (2008). Composition of goat and sheep milk products: An update. Small ruminant research, 79(1), 57-72.

Retnowati, D. S., Kumoro, A. C., \& Budiyati, C. S. (2013). Pembuatan dan Karakterisasi Sabun Susu dengan Proses Dingin. Jurnal Rekayasa Proses, 7(2), 45-50.

Sari, T. I., Herdiana, E., \& Amelia, T. (2010). Pembuatan VCO dengan Metode Enzimatis dan Konversinya Menjadi Sabun Padat Transparan. Jurnal Teknik Kimia, 17(3), 50-58.

Sari, T. I., Kasih, J. P., \& Sari, T. J. N. (2010). Pembuatan Sabun Padat dan Sabun Cair Dari Minyak Jarak. Jurnal Teknik Kimia, 17(1), 28-33.

Setyawardani, T., Rahardjo, A. H., Sulistyowati, M., \& Wasito, S. (2014). Physiochemical and organoleptic features of goat milk kefir made of different kefir grain concentration on controlled fermentation. Animal Production, 16(1), 48-54.

Singh, U.P., Pathak K.K., Khare M.N. dan Sing R.B. (1979). Effect of Leaf Extract of Garlic on Fusarium Oxysporum F. Sp. Cireri, Sclerotinia Sclerotiorum and on Gram Seeds. Mycologia 71 (3), 556-564

Spitz, L. (1996). Soaps and Detergents. A Theoretical and Practical Review. Retrieved from Champaign-Illinois:

Steel, R. G., \& Torrie, J. H. (1996). Principles and Procedures of Statistic: a Biometrical Approach. New York: McGraw-Hill Book Company.

Sukawaty, Y., Warnida, H., \& Artha, A. V. (2016). Formulasi Sediaan Sabun Mandi Padat Ekstrak Etanol Umbi Bawang Tiwai (Eleutherine bulbosa (Mill.) Urb.). Media Farmasi, 13(1), 14-22.

Sumarmono, J., \& Sulistyowati, M. (2015). Fatty acids profiles of fresh milk, yogurt and concentrated yogurt from peranakan etawah goat milk. Procedia Food Science, 3, 216-222.

Wasitaatmadja, S. M. (1997). Penuntun ilmu kosmetik medik. Penerbit Universitas Indonesia, Jakarta, 3(5), 22-23.

Widiyanti, Y. (2009). Kajian Pengaruh Jenis Minyak terhadap Mutu Sabun Transparan. (Skripsi), Institut Pertanian Bogor, Bogor.

Wulansari, P. D., Rahayu, N., \& Ardigurnita, F. (2018). The Potential of Concentrate of Fermented Milk for Natural Antibacterial. Buletin Peternakan, 42(3), 238-243.

Yulianti, R., Nugraha, D. A., \& Nurdianti, L. (2015). Formulasi Sediaan Sabun Mandi Cair Ekstrak Daun Kumis Kucing (Orthosiphon Aristatus (BI) Miq.). Kartika: Jurnal Ilmiah Farmasi, 3(2), 1-11.

Zulkifli, M., \& Estiasih, T. (2014). Sabun dari Distilat Asam Lemak Minyak Sawit : Kajian Pustaka. Jurnal Pangan dan Agroindustri, 2(4), 170-177. 